\title{
Posterior Auricular Muscle Response: Observations in Brainstem Lesions
}

\author{
Beyin Sapı Lezyonlarında Posterior Auriküler Kas Yanıtının Araştırılması
}

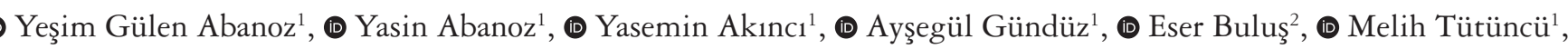
(1) Sabahattin Saip ${ }^{1}$, (1) Meral Erdemir Kizıltan ${ }^{1}$

${ }^{1}$ Istanbul University Cerrahpasa Faculty of Medicine, Department of Neurology, Istanbul, Turkey

${ }^{2}$ Medical Park Gaziosmanpasa Hospital, Clinic of Neurology, Istanbul, Turkey

\begin{abstract}
Objective: Posterior auricular muscle response (PAMR) is a myogenic potential recorded over PAM after auditory stimulation. Its circuit is formed by cochlear and facial nerves with the generator in the brainstem. Here, we investigated whether the addition of a PAMR examination would add additional use in determining or localizing isolated brainstem lesions given that the importance of blink reflex (BR) in determining or localizing brainstem lesions is known. Our hypothesis was that examination of both reflexes would increase clinical utility.

Materials and Methods: We included 34 patients with isolated brainstem lesions (multiple sclerosis, ischemic stroke and cerebellopontine angle schwannoma) and 41 healthy subjects. PAMRs were recorded over the PAM after auditory stimulation. BR was elicited by the electrical stimulation of the supraorbital nerve.

Results: PAMR was present in $82.9 \%$ of healthy subjects, whereas the presence was quite low in the patient group $(38.2 \%, \mathrm{p}=0.001)$. The mean latency of PAMR was delayed in patients compared with healthy subjects $(\mathrm{p}=0.001)$. BR was obtained in all healthy subjects, whereas prolonged latencies or absence of $\mathrm{BR}$ was observed in the patient group. There were no differences according to the different etiologies or localization.

Conclusion: Although the presence of PAMR is quite high, its absence does not always indicate a pathology. However, prolonged latencies almost always suggest an involvement of the PAMR pathway. Likewise, absent PAMR with an abnormal BR provides information for the involvement of brainstem facial nucleus or the proximal part of the facial nerve.
\end{abstract}

Keywords: Posterior auricular muscle response, blink reflex, brainstem, multiple sclerosis, stroke

\section{$\ddot{\mathbf{O} z}$}

Amaç: Posterior auriküler kas yanıtı (PAMR), işitsel uyarı sonrası, PAK üzerinden kaydedilen miyojenik bir potansiyeldir. Devresi, jeneratörü beyin sapında bulunan koklear ve fasiyal sinirler tarafından oluşturulur. Beyin sapı lezyonlarının belirlenmesinde veya lokalize edilmesinde göz kırpma refleksinin (GKR) önemi bilinmektedir, biz de PAMR incelemesinin izole beyin sapı lezyonlarının belirlenmesinde veya lokalize edilmesinde ek bir kullanım sağlayıp sağlamayacağını araştırdık. Bizim hipotezimiz, her iki refleksin incelenmesinin klinik faydayı artıracak olmasıydı.

Gereç ve Yöntem: İzole beyin sapı lezyonu multipl skleroz, iskemik inme ve serebellopontin açı schwannomu olan 34 hasta ve 41 sağlıklı birey çalışmaya alındı. PAMR işitsel uyarı sonrası PAK üzerinden kaydedildi. GKR, supraorbital sinirin elektriksel uyarımı ile elde edildi.

Bulgular: PAMR, săglıklı bireylerin \%82,9'unda mevcutken, hasta grubunda varllı̆ğ oldukça düşüktü (\%38,2, p=0,001). PAMR'nin ortalama latansı hasta bireylerde sağlıklı bireylerle karşılaştırıldığında gecikmişti ( $\mathrm{p}=0,001)$. Tüm sağlıklı bireylerden GKR alınabilmesine karşılık, hasta grubunda GKR latanslarının uzamış olduğu ya da GKR'nin alınamadığı gözlenmiştir. Farklı etiyolojilere veya lokalizasyona göre farklılık yoktu.

Sonuç: PAMR varlığı oldukça yüksek olmasına rağmen, elde edilmemesi her zaman bir patolojiye işaret etmez. Ancak uzamış latanslar hemen her zaman PAMR yolağının tutulumunu düşündürür. Benzer şekilde, anormal GKR ve PAMR yokluğunun bir arada bulunması, beyin sapı fasiyal nükleus veya proksimal fasiyal sinir tutulumuna dair bilgi să̆lar.

Anahtar Kelimeler: Posterior auriküler kas yanıtı, göz kırpma refleksi, beyin sapı, multipl skleroz, inme

Address for Correspondence/Yazışma Adresi: Yasemin Akıncı MD, Istanbul University Cerrahpaşa Faculty of Medicine, Department of Neurology, Istanbul, Turkey Phone: +90 5059985070 E-mail: yasemnaknc@gmail.com ORCID ID: orcid.org/0000-0001-6984-033X

Received/Geliş Tarihi: 10.07.2017 Accepted/Kabul Tarihi: 29.01.2018

${ }^{\circ}$ Copyright 2018 by Turkish Neurological Society

Turkish Journal of Neurology published by Galenos Publishing House. 


\section{Introduction}

Posterior auricular muscle response (PAMR) is a myogenic potential recorded over the PAM after auditory stimulation $(1,2)$. Its circuit is formed by cochlear and facial nerves with the generator in the brainstem (3). The related structures in the brainstem are the superior olivary complex, lateral lemniscus, and inferior colliculus. PAMR is not obtained in a small portion of healthy subjects $(3,4)$. Blink reflex $(\mathrm{BR})$, on the other hand, is classically elicited after supraorbital electrical stimulation or a mechanical tap to the forehead. Lesions in the middle and caudal parts of the brainstem may present with prolonged latencies of BR or an absent response, whereas lesions in the upper brainstem or cerebrum may lead to disinhibition of the facial nucleus and hyperexcitability of BR $(5,6,7,8)$. Thus, BR bears an importance in determining or localizing brainstem lesions. The major clinical use of PAMR is screening for hearing loss in newborns (2). We previously showed PAMR had no synkinetic spread, even in the presence of synkinetic spread of auditory BR and BR (9). However, there may be further clinical uses of PAMR such as the evaluation of facial nerve functions similar to BR or the evaluation of central cochleafacial connections. Here, we investigated whether the addition of a PAMR examination would add an additional use in determining or localizing isolated brainstem lesions. Our hypothesis was that examination of both reflexes would increase clinical utility.

\section{Materials and Methods}

The study included 34 patients with isolated brainstem lesions due to different etiologic factors and 41 age- and sex-matched healthy subjects. The etiologies were relapsing-remitting multiple sclerosis (MS) with isolated brainstem lesion at the time of examination $(n=18)$, first-ever ischemic brainstem stroke with no supratentorial/cerebellar large or small-artery involvement $(n=14)$, and cerebellopontine angle schwannoma $(n=2)$. All magnetic resonance imaging (MRI) studies at the time of investigation were reviewed by three neurologists (Y.A., Y.G.A., E.B.) and lesion locations were noted. The age and sex of patients were recorded. Demographic and MRI findings are shown in Table 1. All electrophysiologic investigations were performed bilaterally under similar conditions when patients were relaxed and seated with their eyes slightly closed using surface $\mathrm{Ag}-\mathrm{AgCl}$ electrodes and Neuropack Sigma MEB-9100, Nihon Kohden Medical, Tokyo, Japan. The approval of this retrospective study was obtained from Istanbul University Cerrahpasa Faculty of Medicine's Clinical Researches Ethics Committee (file no: 01.01/114387, date: 01.07.2014).

\section{Posterior Auricular Muscle Response}

The recordings from PAM were made in accordance with the previously published reports $(2,9)$. The active electrode was placed on the surface of the skin directly overlying the PAM, and the reference electrode was placed on the pinna. For auditory stimulations, a monophasic $100 \mathrm{~ms}, 105 \mathrm{~dB}$, click auditory stimulus was delivered bilaterally through headphones. Recordings were repeated five times at random intervals of 2 to $5 \mathrm{~min}$. The analysis time was adjusted as $30 \mathrm{~ms}$. The filter settings were $2 \mathrm{kHz}$ high-cut and $20 \mathrm{~Hz}$ low-cut.

\section{Blink Reflex}

BR was recorded according to the standard techniques (10). The electrodes were placed on bilateral orbicularis oculi (OOc) muscles. Active electrode was on the lower eyelid with a reference electrode located on the lateral orbital margin. The ground electrode was placed on the forehead. The stimulus was applied on the ophthalmic branch of the trigeminal nerve at its exit from the supraorbital foramen using a bipolar percutaneous electrode. The electrical stimulus was $0.2 \mathrm{~ms}$ in duration and its intensity was three times that of the $\mathrm{R} 2$ threshold. Recordings were repeated five times at random intervals of 2 to $5 \mathrm{~min}$. The analysis time was $20 \mathrm{~ms}$ per division. The filter settings were $2 \mathrm{kHz}$ high-cut and $20 \mathrm{~Hz}$ low-cut.

\section{Statistical Analysis}

Bilateral non-rectified responses were recorded after each stimulus. The analysis was composed of five consecutive reflex responses with the shortest latencies for each patient. The onset latencies from first deflections of the reflex activity were measured using cursors. Responses were considered present if the sum of amplitudes of positive and negative deflections from the baseline were greater than $50 \mu \mathrm{V}$. Latencies of BR and PAMR were considered prolonged when they were beyond the mean latency +2 standard deviations (SDs) of healthy subjects. Response asymmetry was accepted when the response of one side was normal and the response of the other side was absent or prolonged, or when there was a latency difference of more than 2 SDs.

The analyses of the data were performed using the SPSS 17.5 statistical software package. We compared the latencies in patients with brainstem lesions and healthy subjects using the MannWhitney U test. The responses were grouped as normal, bilaterally absent, unilaterally absent, bilaterally prolonged or asymmetric, which were then compared between the two groups using the chi-square test. Comparisons of latencies and the presence of abnormalities were also performed among patients with different etiologies. The final analysis included the relationship between reflex abnormalities and lesion locations (intra-axial vs. extraaxial or right, left vs. midline). A p value of $<0.05$ was considered statistically significant.

\section{Results}

\section{Posterior Auricular Muscle Response}

The presence of PAMR was $82.9 \%(\mathrm{n}=34)$ in healthy subjects, whereas it was $38.2 \%(\mathrm{n}=13)$ in the patient group $(\mathrm{p}=0.001$, Table 2). PAMR was absent bilaterally in 11 (32.4\%) patients and unilaterally in 7 (20.6\%) patients. Additionally, the mean latency was delayed in $3(8.8 \%)$ patients. The mean PAMR latency was also delayed in patients $(\mathrm{p}=0.001)$. There were no differences between the subgroups according to the different etiologies (Table 3) or the locations within the brainstem.

\section{Blink Reflex}

The supraorbital electrical stimulation elicited early (R1) and late responses (R2-R2c) over the $\mathrm{OOc}(\mathrm{BR})$ in all healthy subjects. However, there were patients with unilateral or bilateral absent responses, or prolonged latencies (Table 2). The mean latencies of $\mathrm{R} 1, \mathrm{R} 2$, and R2c were also significantly prolonged in the patient 
Table 1. Demographic and clinical features of patients and healthy subjects

\begin{tabular}{|c|c|c|c|c|c|c|}
\hline & $\begin{array}{l}\text { Patients } \\
\mathrm{n}=34\end{array}$ & $\begin{array}{l}\text { Healthy subjects } \\
n=41\end{array}$ & $\mathrm{p}$ & $\begin{array}{l}\text { Stroke patients } \\
n=14\end{array}$ & $\begin{array}{l}\text { MS patients } \\
\mathrm{n}=18\end{array}$ & $\begin{array}{l}\text { Tumor patients } \\
\mathrm{n}=2\end{array}$ \\
\hline Age, y & $44.3 \pm 17.4$ & $43.5 \pm 12.1$ & 0.808 & $59.3 \pm 13.9$ & $32.2 \pm 8.6$ & $55.0 \pm 22.6$ \\
\hline \multicolumn{7}{|l|}{ MRI location, n (\%) } \\
\hline Mesencephalon & $0(0)$ & - & - & $0(0)$ & 0 & 0 \\
\hline Pons & $20(58.8)$ & & & $10(71.4)$ & $10(55.5)$ & 0 \\
\hline Cerebellopontine angle & $2(5.9)$ & & & $0(0)$ & $0(0)$ & $2(100)$ \\
\hline
\end{tabular}

Table 2. Blink reflex and posterior auricular muscle response parameters in patients and healthy subjects

\begin{tabular}{llll|} 
& $\begin{array}{l}\text { Patient } \\
\text { group } \\
\mathbf{n}=34\end{array}$ & $\begin{array}{l}\text { Healthy } \\
\text { subjects } \\
\mathrm{n}=41\end{array}$ & $\mathrm{p}$ \\
& 11.6 & 10.1 & $<0.001$ \\
R/R1 latency & 11.4 & 10.1 & 0.010 \\
L/R2 latency & 37.5 & 32.7 & 0.001 \\
R/R2 latency & 38.5 & 32.5 & $<0.001$ \\
L/R2 latency & 39.3 & 33.1 & $<0.001$ \\
R/R2C latency & 39.7 & 32.9 & $<0.001$ \\
L/R2C latency & 11.5 & 9.3 & 0.001 \\
R/PAMR latency & 11.4 & 9.3 & 0.001 \\
L/PAMR latency & $14(41.2)$ & $0(0)$ & $<0.001$ \\
R1 abnormality n (\%) & $9(26.5)$ & & \\
Asymmetrical/long & $1(2.9)$ & & \\
Absent bilaterally & $2(5.9)$ & & \\
Absent unilaterally & $2(5.9)$ & & \\
Long bilaterally & $11(32.3)$ & $0(0)$ & 0.001 \\
R2 abnormality n (\%) & $6(17.6)$ & & \\
Asymmetrical/long & $0(0)$ & & \\
Absent bilaterally & $1(2.9)$ & & \\
Absent unilaterally & $4(11.8)$ & & \\
Long bilaterally & $13(38.2)$ & $0(0)$ & \\
R2C abnormality n (\%) & $4(11.8)$ & & \\
Asymmetrical/long & $0(0)$ & & \\
Absent bilaterally & $3(8.8)$ & & \\
Absent unilaterally & $6(17.6)$ & & \\
Long bilaterally & $3(8.8)$ & $0(0)$ & \\
PAMR & $13(38.2)$ & $34(82.9)$ & 0.001 \\
Normal & $11(32.4)$ & $5(12.2)$ & \\
Absent bilaterally & $7(20.6)$ & $2(4.9)$ & \\
Absent unilaterally & & & \\
Long bilaterally & & \\
PAMR: Posterior auricular muscle response & \\
\hline
\end{tabular}

group compared with the healthy subjects. The comparisons of subgroups according to the different etiologies showed that the frequencies of R1, R2, and R2c abnormalities were similar (Table
Table 3. Blink reflex and posterior auricular muscle response parameters in patient subgroups according to different etiologies

\begin{tabular}{|c|c|c|c|c|}
\hline & $\begin{array}{l}\mathrm{CPA} \\
\mathrm{Tm} \\
\mathrm{n}=2\end{array}$ & $\begin{array}{l}\text { Stroke } \\
n=14\end{array}$ & $\begin{array}{l}\text { MS } \\
n=18\end{array}$ & $\mathrm{p}$ \\
\hline R1 abnormality n (\%) & & & & 0.599 \\
\hline Normal & $2(100)$ & $9(64.3)$ & $9(50.0)$ & \\
\hline Asymmetrical long & - & $4(28.6)$ & $5(27.8)$ & \\
\hline Bilateral absent & - & $1(7.1)$ & - & \\
\hline Unilateral absent & - & - & $2(11.1)$ & \\
\hline Bilateral prolonged & - & - & $2(11.1)$ & \\
\hline R2 abnormality n (\%) & & & & 0.889 \\
\hline Normal & $2(100)$ & $10(71.4)$ & $11(61.1)$ & \\
\hline Asymmetrical long & - & $2(14.3)$ & $4(22.2)$ & \\
\hline Bilateral absent & - & - & - & \\
\hline Unilateral absent & - & - & $1(5.6)$ & \\
\hline Bilateral prolonged & - & $2(14.3)$ & $2(11.1)$ & \\
\hline R2C abnormality n (\%) & & & & 0.650 \\
\hline Normal & $1(50.0)$ & $9(64.3)$ & $11(61.1)$ & \\
\hline Asymmetrical long & $1(50.0)$ & $2(14.3)$ & $1(5.6)$ & \\
\hline Bilateral absent & - & - & - & \\
\hline Unilateral absent & - & $1(7.1)$ & $2(11.1)$ & \\
\hline Bilateral prolonged & - & $2(14.3)$ & $4(22.2)$ & \\
\hline PAMR abnormality $\mathrm{n}(\%)$ & & & & 0.948 \\
\hline Normal & $1(50.0)$ & $5(35.7)$ & 7 (38.9) & \\
\hline Asymmetrical long & - & - & - & \\
\hline Bilateral absent & $1(50.0)$ & $4(28.6)$ & $6(33.3)$ & \\
\hline Unilateral absent & - & $3(21.4)$ & $4(22.2)$ & \\
\hline Bilateral prolonged & - & $2(14.3)$ & $1(5.6)$ & \\
\hline
\end{tabular}

3), which was also true for comparisons of groups with intra- or extra-axial lesions; however, there were too few patients in the extra-axial group to perform a statistical analysis.

Comparisons of Posterior Auricular Muscle Response and Blink Reflex Abnormalities

Abnormalities of BR and PAMR in the patient group were quite similar. Out of seven patients with bilaterally prolonged R1, 
four had no PAMR and one had asymmetrically prolonged PAMR Five patients out of 11 patients with asymmetrically prolonged R1 latency had ipsilateral absent PAMR, whereas one showed bilaterally absent PAMR. Patients with normal R1 $(n=15)$ displayed bilaterally absent PAMR $(n=2)$, unilaterally absent PAMR $(n=2)$, and asymmetrically prolonged PAMR latency $(n=3)$. All patients with bilaterally prolonged R2 also displayed abnormalities of PAMR: bilateral absent PAMR in five patients, unilateral absent PAMR in two patients and significantly prolonged PAMR in one patient. For asymmetrically prolonged R2 latency in five patients, PAMR was absent bilaterally in one patient and unilaterally in one patient. PAMR was absent bilaterally in four patients and unilaterally in four patients out of 20 patients with normal R2. Out of 13 patients who exhibited both abnormalities of R1 and $\mathrm{R} 2$, none had normal PAMR. The Figure 1 shows examples of a normal and an asymmetrically prolonged PAMR.

\section{Discussion}

The major finding of this study is that PAMR is abnormal in a way similar to that observed in BR recordings in patients with brainstem lesions. BR after trigeminal stimulation is composed of two responses, ipsilateral R1 with shorter latency and bilateral R2 with longer latencies and multiple phases. R2 responses are generated in the spinal trigeminal complex, in the interneurons in the reticular formation, and in facial motoneurons (10). In previous studies, brainstem lesions, especially lower ones, were found to lead to prolonged latency or absent responses of BR after trigeminal stimulation (6). The diagnostic potential of BR was an important issue before the neuroimaging era (11). A recent study claimed the importance of BR in helping in the diagnosis and follow-up of patients with relapsing-remitting MS (12). PAMR was enhanced in patients with intracranial lesions, similar to deep tendon reflexes ipsilateral to the corticospinal tract findings $(13,14)$. Our study also confirmed that PAMR shows abnormalities in patients with brainstem lesions. The major factor limiting its clinical use is the absence of PAMR in some healthy subjects, probably because it is a rudimentary muscle $(2,3)$. However, the frequency of presence is quite high and latency is consistent. For this reason, the use of PAMR in combination with BR as well as the use of latency asymmetry rather than its absence seems more useful. In the literature, generally the peak latencies used for PAMR in
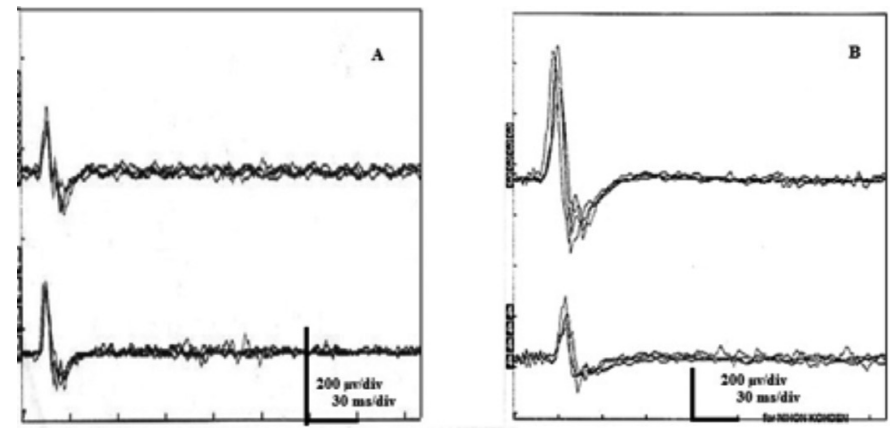

Figure 1. A) Shows an example of a normal posterior auricular muscle response. B) Shows an example of an asymmetrically prolonged posterior auricular muscle response. normal individuals are $12-13 \mathrm{~ms}(2,3)$. We used onset latency of initial deflection for PAMR because we measured onset latencies of initial deflection for other reflexes, and thus the responses in the healthy subjects were shorter compared with those in some previous reports. The responses are prolonged in both extracranial and intracranial lesions. Prolonged latencies almost always indicate an involvement of the PAMR pathway. Likewise, an absent PAMR with an abnormal BR provides information for involvement of the brainstem facial nucleus or the proximal part of the facial nerve. Although bilateral or unilateral prolonged responses were more frequent in the MS group, there was no statistical significance between the stroke and MS groups. Therefore, we can say that abnormal findings do not differ among different etiologic factors. The main limitation of the study is the small number of patients with cerebellopontine angle tumors. Although our findings are similar to previous reports, we should avoid direct conclusions regarding this group of patients. Second, the absence of PAMR in healthy subjects raises the question of whether any pathology exists in this group. However, this phenomenon was previously discussed in articles covering PAMR recordings and was attributed to the agenesis of this small muscle $(2,3)$. Although we did not perform MRI in these subjects, thorough neurologic examinations were normal.

\section{Conclusion}

PAMR has a consistent latency. Although its absence in some healthy subjects limits its clinical use, recordings of PAMR with $\mathrm{BR}$ and interpretation of latency asymmetry rather than the absence of PAMR may provide evidence for brainstem involvement.

\section{Ethics}

Ethics Committe Aproval: The approval of this retrospective study was obtained from Istanbul University Cerrahpasa Faculty of Medicine's Clinical Researches Ethics Committee (file no: 01.01/114387, date: 01.07.2014).

Informed Consent: Consent form was filled out by all participants.

Peer-review: Externally and internally peer-reviewed.

Authorship Contributions

Surgical and Medical Practices: Y.G.A., Y.A., Y.A., A.G., E.B., M.T., S.S., M.E.K., Concept: Y.G.A., Y.A., Y.A., A.G., E.B., M.T., S.S., M.E.K., Design: Y.G.A., Y.A., Y.A., A.G., E.B., M.T., S.S., M.E.K., Data Collection or Processing: Y.G.A., Y.A., Y.A., A.G., E.B., M.T., S.S., M.E.K., Analysis or Interpretation: Y.G.A., Y.A., Y.A., A.G., E.B., M.T., S.S., M.E.K., Literature Search: Y.G.A., Y.A., Y.A., A.G., E.B., M.T., S.S., M.E.K., Writing: Y.G.A., Y.A., Y.A., A.G., E.B., M.T., S.S., M.E.K.

Conflict of Interest: No conflict of interest was declared by the authors.

Financial Disclosure: The authors declared that this study received no financial support.

\section{References}

1. Dus V, Wilson SJ. The click-evoked post-auricular myogenic response in normal subjects. Electroencephalogr Clin Neurophysiol 1975;39:523-525.

2. O'Beirne GA, Patuzzi RB. Basic properties of the sound-evoked postauricular muscle response (PAMR). Hear Res 1999;138:115-132. 
3. Patuzzi RB, O’Beirne GA. Effects of eye rotation on the sound-evoked postauricular muscle response (PAMR). Hear Res 1999;138:133-146.

4. Gündüz A, Kızıltan ME, Uygunoğlu U, et al. Understanding the features of posterior auricular muscle response in a facial nerve disease prototype. Kulak Burun Bogaz Ihtis Derg 2013;23:173-178.

5. Cabib C, Llufriu S, Martinez-Heras E, Saiz A, Valls-Solé J. Abnormal control of orbicularis oculi reflex excitability in multiple sclerosis. PLoS One 2014;9:e103897.

6. Cruccu G, Iannetti GD, Marx JJ, et al. Brainstem reflex circuits revisited. Brain 2005;128:386-394.

7. Degirmenci E, Erdogan C, Bir LS. Correlation between blink reflex abnormalities and magnetic resonance imaging findings in patients with multiple sclerosis. Acta Neurol Belg 2013;113:265-269.

8. Mikropoulos EH, Papathanasiou AA, Hadjigeorgiou G, Tsironi E, Papadimitriou A. Supratentorial multiple sclerosis lesions affect the blink reflex test. Open Neurol J 2010;4:92-99.
9. Kiziltan ME, Gündüz A, Sahin R. Auditory evoked blink reflex and posterior auricular muscle response: observations in patients with HFS and PFS. J Electromyogr Kinesiol 2010;20:508-512.

10. Kimura J. Electrodiagnosis in diseases of nerve and muscle: principles and practice. 3rd ed. New York: Oxford University Press, 2001.

11. Kimura J. Electrically elicited blink reflex in diagnosis of multiple sclerosis. Review of 260 patients over a seven-year period. Brain 1975;98:413426.

12. Brooks JB, Jardim MR, Papais-Alvarenga RM, Fragoso YD. There is still a role for the blink reflex in the diagnosis and follow-up of multiple sclerosis. Clin Neurophysiol 2015;126:743-747.

13. Funahashi K, Imae S, Kuwata T, et al. Postauricular response in motor paresis with intracranial lesions. Neurol Med Chir (Tokyo) 1992;32:566-571.

14. Hammond EJ, Wilder BJ. Enhanced auditory postauricular evoked responses after corticobulbar lesions. Neurology 1985;35:278-281. 